Acta vet. scand. $1968,9,168-173$.

From the Department of Medicine II, Royal Veterinary College, Stockholm, Sweden.

\title{
THE GLYCOGENIC PROPERTIES OF BUTYRIC ACID
}

\author{
By \\ J. Luthman and G. Jonson
}

The importance of butyric acid in the intermediate metabolism of the ruminants has long been a matter for discussion. The conclusions concerning its glycogenic properties have in most cases been made from results obtained after intravenous administration. Kronfeld (1957) stated that blood glucose increases after butyrate infusion when the glucose level is initially low, and decreases when the level is initially high. The incorporation of labelled butyrate carbon into glucose has been studied by Black et al. (1961) and Simesen et al. (1963). Simesen et al. administered the butyrate both intravenously and intraruminally. After intravenous administration the specific activity of blood glucose was higher than after intraruminal injection. Their data further indicated a different manner of utilization depending on which of the two routes of administration was employed. This was apparently due to metabolism of the butyrate in the rumen wall when given intraruminally. Ash et al. (1964) obtained a rise in blood glucose after intravenous butyrate infusion and, when labelled butyrate was used, the specific activity of blood glucose was very low. From the results of butyrate and glucose infusions it was concluded that butyrate affects glucose metabolism by other mechanisms than by its conversion to glucose.

Phillips et al. (1965) injected butyrate intravenously in hypoglycemic lambs. Besides a rise in blood glucose there was an increase in ketone bodies and a drop in the plasma level of nonesterified fatty acids (NEFA). The phosphorylase activity increased in the liver and liver glycogen decreased about $50 \%$. 
As some of the animals were adrenalectomized the action of catecholamines could be abolished. When butyrate was given intraruminally there was no rise in blood glucose and the plasma concentration of NEFA decreased (Menahan et al. 1966a).

In this paper experiments are described where butyric acid was given intravenously and intraruminally and where changes in blood glucose and NEFA were studied.

\section{MATERIAL AND METHODS}

Three cows and eight sheep, both males and females, were used. One ewe with severe pregnancy toxemia, previously treated with glucose and corticosteroids, was included in the experiment. One cow, provided with a permanent rumen fistula, was non-pregnant and almost dry, while the two others were in late pregnancy.

Butyric acid at an amount of $2.5 \mathrm{mM} / \mathrm{kg}$ body weight, buffered with saturated $\mathrm{NaOH}$ to $\mathrm{pH} 7.2$ was injected intravenously. An attempt to use calves was made, but the injections were followed by severe coughing and muscle tremor. These animals were excluded from further experimentation. In the sheep no complications occurred when the injections were given over $3-4 \mathrm{~min}$.

Intraruminally the acid was given at doses of 2.5 and $5 \mathrm{mM} / \mathrm{kg}$ body weight. When given to sheep the acid was diluted with saline to a volume of $50 \mathrm{ml}$ and injected directly into the rumen. Before use in the pregnant cows the acid was buffered with saturated $\mathrm{NaOH}$ to $\mathrm{pH} 6.5$ and given by stomach tube. In the third cow the acid was injected directly into the ingesta through the rumen fistula. Blood was collected from a jugular vein. Blood glucose was determined according to the glucose oxidase method (Reagents from $\mathrm{AB}$ Kabi, Stockholm) and NEFA according to Dole (1956).

\section{RESULTS}

The changes in blood glucose after intravenous injection of $2.5 \mathrm{mM} / \mathrm{kg}$ body weight of butyric acid are shown in Fig. 1. In the normal animals there was a sharp rise, while the ewe with pregnancy toxemia remained nearly unaffected. The NEFA values obtained immediately after the injection showed great irregularities. The high blood concentration of butyric acid apparently interfered with the method of analysis used. 


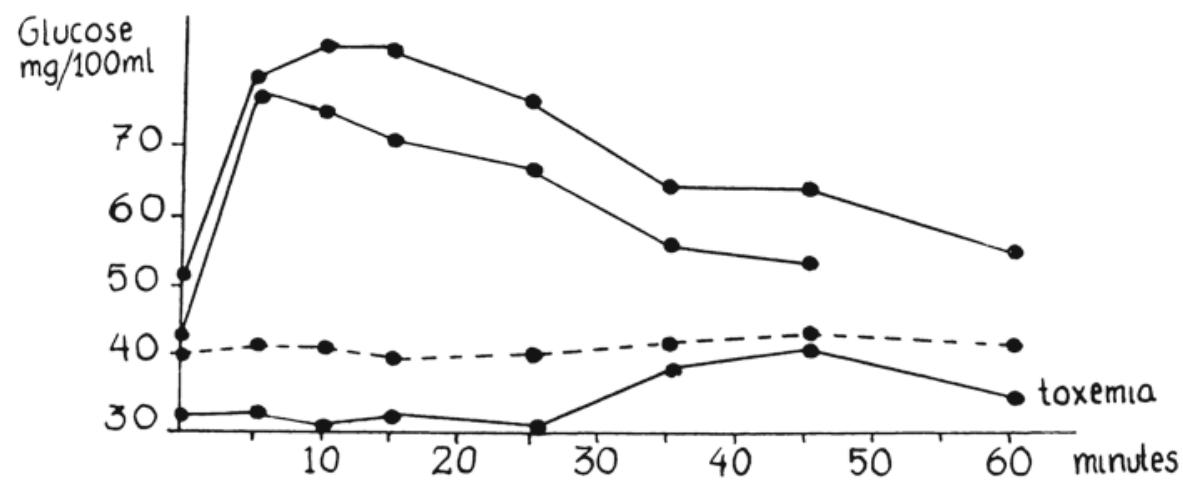

Figure 1. The effect on blood glucose of intravenous injection of butyric acid in normal sheep and in a ewe with severe pregnancy toxemia —. The control animal is given only saline -.....

T a b l e 1. Changes in blood glucose and NEFA after intraruminal injection of butyric acid.

\begin{tabular}{|c|c|c|c|c|c|c|c|}
\hline \multirow{2}{*}{\multicolumn{2}{|c|}{ Animal }} & \multirow{2}{*}{$\begin{array}{l}\text { Butyric acid } \\
\mathrm{mM} / \mathrm{kg}\end{array}$} & \multicolumn{5}{|c|}{ Minutes after injection } \\
\hline & & & 0 & 30 & 60 & 120 & 180 \\
\hline & & & \multicolumn{5}{|c|}{ Glucose $\mathrm{mg} / 100 \mathrm{ml}$} \\
\hline Sheep & 1 & - & 42 & 46 & 44 & 42 & 44 \\
\hline, & 1 & 2.5 & 46 & 44 & 42 & 40 & 40 \\
\hline$"$ & 2 & $\eta$ & 54 & 54 & 50 & 46 & 50 \\
\hline$”$ & 3 & $"$ & 43 & 43 & 45 & 45 & 48 \\
\hline$"$ & 4 & $"$ & 40 & 40 & 40 & 39 & 44 \\
\hline Cow & 1 & , & 40 & 42 & 38 & 38 & 39 \\
\hline$\eta$ & 2 & $"$ & 39 & 40 & 39 & 37 & 43 \\
\hline 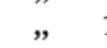 & 1 & 5 & 39 & 39 & 32 & 35 & 39 \\
\hline$"$ & 3 & 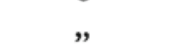 & 41 & 41 & 36 & 36 & 41 \\
\hline
\end{tabular}

\begin{tabular}{|c|c|c|c|c|c|c|c|}
\hline \multirow{2}{*}{\multicolumn{2}{|c|}{ Sheep 1}} & \multirow[b]{2}{*}{-} & \multicolumn{5}{|c|}{ NEFA mE/l } \\
\hline & & & 0.300 & 0.280 & 0.285 & 0.305 & 0.255 \\
\hline$”$ & 1 & 2.5 & 0.345 & 0.270 & 0.240 & 0.190 & 0.245 \\
\hline , & 2 & , & 0.278 & 0.190 & 0.160 & 0.175 & 0.165 \\
\hline , & 3 & , & 0.260 & 0.210 & 0.160 & 0.150 & 0.265 \\
\hline$"$ & 4 & $"$ & 0.395 & 0.335 & 0.320 & 0.250 & 0.220 \\
\hline Cow & 1 & , & 0.195 & 0.130 & 0.130 & 0.125 & 0.095 \\
\hline , & 2 & 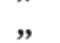 & 0.185 & 0.150 & 0.145 & 0.130 & 0.100 \\
\hline " & 1 & 5 & 0.275 & 0.170 & 0.230 & 0.190 & 0.260 \\
\hline$”$ & 3 & ” & 0.175 & 0.145 & 0.110 & 0.095 & 0.080 \\
\hline
\end{tabular}


The results of intraruminal administration are summarized in Table 1. Blood glucose did not seem to be affected, while in most cases NEFA were depressed by about $50 \%$. The plasma concentration of NEFA was higher in the sheep than in the cows, but was depressed in both kinds of animals.

\section{DISCUSSION}

In contrast to the findings of Kronfeld (1957), Phillips \& Black (1966) have shown that butyric acid increases blood glucose also in hyperglycemic animals when given intravenously. This would be expected if butyric acid acts by promoting glycogenolysis as was suggested by Phillips et al. (1965). The results shown in Fig. 1 are in conformity with this hypothesis. The liver of the ewe with pregnancy toxemia probably did not contain glycogen enough to respond to glycogenolytic agents.

When the same amount of butyric acid was injected into the rumen blood glucose was not altered (Table 1). Most of the butyrate seemed to be metabolized in the rumen wall, as described by Pennington (1952), and did not appear in the circulating blood in amounts sufficient to promote glycogenolysis. Even when the double dose, $5 \mathrm{mM} / \mathrm{kg}$ body weight, was given, insignificant amounts seemed to escape being metabolized.

The depressant action on NEFA is discussed by Menahan et al. (1966a). These authors infused butyric acid at rates of 8 and $16 \mathrm{mM} / \mathrm{kg} / 24 \mathrm{hrs}$. intraruminally to goats. In the animals where the concentration of ketone bodies was very high, the plasma concentration of NEFA was depressed. In another work, Menahan et al. (1966b) obtained a significant decrease in the NEFA level after infusion of $\beta$-hydroxybutyric acid. Madison et al. (1964) have shown that the effect on blood glucose and NEFA after infusion of ketone bodies is due to an increased secretion of insulin.

From the above findings it can be assumed that butyric acid depresses the NEFA level in two different ways. When injected intravenously the resulting hyperglycemia decreases the NEFA level by increasing the esterification rate in the adipose tissue. After oral or intraruminal administration the butyric acid is metabolized to ketone bodies in the rumen wall and thus depresses the NEFA level by promoting the secretion of insulin.

During natural conditions butyrate does not occur in significant amounts in the blood of ruminants (Cook \& Miller 1965), and it seems questionable whether butyrate can influence blood 
glucose concentration by increasing glycogenolysis. The butyric acid which is produced in the rumen is probably completely metabolized in the rumen wall and can affect blood glucose and NEFA only by increasing the concentration of ketone bodies.

\section{REFERENCES}

Ash, R. W., R. J. Pennington \& R. S. Reid: The effect of short-chain fatty acids on blood glucose concentration in sheep. Biochem. J. 1964, 90, 353-360.

Black, A. L., M. Kleiber \& A. M. Brown: Butyrate metabolism in the lactating cow. J. biol. Chem. 1961, 136, 2399-2403.

Cook, R. M. \& L. D. Miller: Utilization of volatile fatty acids in ruminants. I. Removal of them from portal blood by the liver. J. Dairy Sci. 1965, 48, 1339-1345.

Dole, V. P.: A relation between non-esterified fatty acid in plasma and the metabolism of glucose. J. clin. Invest. 1956, 35, 150-154.

Kronfeld, D. S.: The effect on blood sugar and ketone bodies of butyrate, acetate and $\beta$-OHbutyrate infused into sheep. Aust. J. exp. Biol. med. Sci. 1957, 35, 257-265.

Madison, L. L., D. Mebane, R. H. Unger \& A. Lochner: The hypoglycemic action of ketone bodies. II. Evidence for a stimulatory feed-back of ketones on the pancreatic beta cells. J. clin. Invest. 1964, 43, 408-415.

Menahan, L. A., L. H. Schultz \& W. G. Hoekstra: Factors affecting ketogenesis from butyric acid in the ruminant. J. Dairy Sci. 1966a, $49,835-845$.

Menahan, L. A., L. H. Schultz\&W. G. Hoekstra: Relationship of ketone body metabolism and carbohydrate utilization to fat metabolism in the ruminant. J. Dairy Sci. 1966 b, 49, 957-961.

Pennington, R. J.: The metabolism of short-chain fatty acids in sheep. I. Fatty acid utilization and ketone body production by rumen epithelium and other tissues. Biochem. J. 1952, 51, 251-258.

Phillips, R. W., A. L. Black \& F. Moller: Butyrate induced glycogenolysis in hypoglycemic lambs. Life Sci. 1965, 4, 521- 525 .

Phillips, R. W. \& A. L. Black: The effect of volatile fatty acids on plasma glucose concentration. Comp. Biochem. Physiol. 1966, $18,527-536$.

Simesen, M. G., A. L. Black, R. L. Luick \& M. Kleiber: Comparison of intravenous and intraruminal administration of $\mathrm{C}-14$ labelled butyrate to lactating cows. Nord. Vet.-Med. 1963, 15, 137-158.

\section{SUMMARY}

When butyric acid was injected intravenously at an amount of $2.5 \mathrm{mM} / \mathrm{kg}$, blood glucose rose markedly in normal sheep. In a ewe with pregnancy toxemia blood glucose did not change. When the same amount was injected intraruminally to sheep and cows, the plasma level of non-esterified fatty acids, NEFA, was in most cases decreased 
by about $30-50 \%$, while blood glucose remained almost unchanged. The same results were obtained when the double amount, $5 \mathrm{mM} / \mathrm{kg}$, was used. The depressant effect of butyric acid on NEFA after intravenous and intraruminal administration is discussed. When butyrate occurs in the circulating blood a breakdown of liver glycogen is induced and the resulting hyperglycemia causes a decrease in the NEFA level. The butyric acid which is infused into or produced in the rumen is probably completely metabolized to ketone bodies in the rumen epithelium and depresses NEFA indirectly by increasing the production of insulin.

\section{ZUSAMMENFASSUNG}

Die glykogenen Eigenschaften von Buttersäure.

Intravenöse Injektion von Buttersäure, $2,5 \mathrm{mM} / \mathrm{kg}$, verursachte bei normalen Schafen eine scharfe Blutzuckersteigerung. Bei einem trächtigen Schaf mit schwerer Acidose wurde die Blutzuckersteigerung nicht merkbar. Als dieselbe Menge von Buttersäure in den Pansen injiciert wurde, wurde die Plasmakonzentration von nicht veresterten Fettsäuren, NEFA, 30 bis $\mathbf{5 0} \%$ vermindert, aber die Konzentration von Glukose wurde fast unverändert. Dasselbe Resultat wurde, wenn man $5 \mathrm{mM} / \mathrm{kg}$ von Buttersäure in den Pansen injiciert, erhalten. Buttersäure kann vermutlich die Plasmakonzentration von NEFA auf zwei verschiedene Wege vermindern. Wenn die Buttersäure durch intravenöse Injektion zugeführt ist, steigt die Glykogenolyse in der Leber, und die resultierende Hyperglykämie senkt NEFA. Nach oraler Zufuhr oder Zufuhr direkt in den Pansen wird die Buttersäure an Ketonkörperchen im Pansenepithelium metabolisiert. Die vermehrte Konzentration von Ketonkörperchen stimuliert die Insulinproduktion mit einer Senkung von NEFA als Resultat.

\section{SAMMANFATTNING}

Smörsyrans glykogena egenskaper.

Intravenös injektion av smörsyra i en mängd av $2,5 \mathrm{mM} / \mathrm{kg}$ gav hos normala får en kraftig blodglykosstegring. Hos en dräktig tacka med acidos uteblev glykosstegringen. När samma mängd smörsyra injicerades direkt $\mathrm{i}$ våmmen sjönk plasmakoncentrationen av icke-

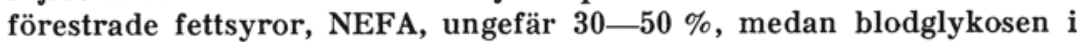
stort sett förblev oförändrad. Resultatet blev det samma när den dubbla mängden smörsyra, $5 \mathrm{mM} / \mathrm{kg}$, injicerades. Smörsyrans inverkan på plasmakoncentrationen av NEFA kan förmodligen ske på två olika sätt. När smörsyra injiceras intravenöst, ökar glykogenolysen, och den resulterande hyperglykämien hämmar mobiliseringen av fettsyror. Efter oral eller intraruminal tillförsel metaboliseras smörsyran till ketonkroppar i våmepitelet. Den ökade koncentrationen av ketonkroppar stimulerar produktionen av insulin, som sänker plasmakoncentrationen av NEFA. 